\title{
Preparation, characterization and photocatalytic activity of activated charcoal from microalgae for photocatalytic degradation of rhodamine B dye
}

\section{(Preparação, caracterização e atividade fotocatalítica de carvão ativado a partir de microalgas para degradação fotocatalítica do corante rodamina $B$ )}

\author{
V. M. Figueiredo ${ }^{1}$, J. B. Lourenço ${ }^{1}$, N. J. S. de Vasconcellos ${ }^{2}$, W. L. da Silva ${ }^{1,3 *}$ \\ ${ }^{1}$ Universidade Franciscana, Curso de Engenharia Química, 97010-032, Santa Maria, RS, Brazil \\ ${ }^{2}$ Universidade Franciscana, Curso de Engenharia Ambiental e Sanitária, Santa Maria, RS, Brazil \\ ${ }^{3}$ Universidade Franciscana, Programa de Pós-Graduação em Nanociências, Santa Maria, RS, Brazil
}

\begin{abstract}
The need to adopt measures that reduce the persistence of pollutants in the environment is notorious, in order to promote the correct disposal and treatment of effluents. This study aimed to prepare, characterize, and evaluate the photocatalytic activity of activated charcoal obtained from the residual biomass of Chlorella pyrenoidosa microalgae for Rhodamine B (RhB) dye degradation. The samples were characterized by X-ray diffraction, Fourier-transform infrared spectroscopy, $\mathrm{N}_{2}$ porosimetry, and zeta potential. To evaluate the photocatalytic activity, experiments were carried out in a stirred batch reactor. The activated charcoal prepared from microalgae biomass showed the better photocatalytic activity in the degradation of the RhB dye of $75.5 \%$ under ultraviolet radiation $\left(\mathrm{k}=0.0121 \mathrm{~min}^{-1}\right)$, and $66.5 \%$ under visible radiation $\left(\mathrm{k}=0.0091 \mathrm{~min}^{-1}\right)$, while the commercial $\mathrm{ZnO}$ achieved $92.5 \%\left(\mathrm{k}=0.0158 \mathrm{~min}^{-1}\right)$ and $16.6 \%\left(\mathrm{k}=0.0032 \mathrm{~min}^{-1}\right)$ for ultraviolet and visible radiation, respectively. Moreover, the activation/carbonization process used for the preparation of activated charcoal from microalgae biomass promoted changes in the structural, textural, and catalytic properties of the prepared samples.
\end{abstract}

Keywords: dyes, heterogeneous photocatalysis, Chlorella pyrenoidosa, degradation.

\section{Resumo}

É notória a necessidade de adotar medidas que reduzam a persistência de poluentes no meio ambiente, a fim de promover o correto descarte e tratamento de efluentes. Este trabalho teve como objetivo preparar, caracterizar e avaliar a atividade fotocatalítica do carvão ativado obtido a partir da biomassa residual de microalga Chlorella pyrenoidosa para degradação do corante Rodamina $B(R h B)$. As amostras foram caracterizadas por difração de raios $X$, espectroscopia no infravermelho por transformada de Fourier, porosimetria de $\mathrm{N}_{2}$ e potencial zeta. Para avaliar a atividade fotocatalítica, os experimentos foram realizados em um reator em batelada agitado. O carvão ativado preparado a partir de biomassa de microalgas apresentou melhor atividade fotocatalítica na degradação do corante $\mathrm{RhB}$ de 75,5\% sob radiação ultravioleta $\left(k=0,0121 \mathrm{~min}^{-1}\right)$ e 66,5\% sob radiação visível $\left(k=0,0091 \mathrm{~min}^{-1}\right)$, enquanto o $\mathrm{ZnO}$ comercial atingiu 92,5\% $\left(k=0,0158 \mathrm{~min}^{-1}\right)$ e 16,6\% $\left(k=0,0032 \mathrm{~min}^{-1}\right)$ para radiação ultravioleta e visível, respectivamente. Além disso, o processo de ativação/carbonização utilizado na preparação de carvão ativado a partir de biomassa de microalgas promoveu mudanças nas propriedades estruturais, texturais e catalíticas das amostras preparadas.

Palavras-chave: corantes, fotocatálise heterogênea, Chlorella pyrenoidosa, degradação.

\section{INTRODUCTION}

Currently, contamination of the aquatic environment has been a matter of global preoccupation, since the potential increase of the toxicity and persistent organic pollutants in the environment [1-3]. Moreover, several industrial sectors, such as textiles, food, and pharmaceuticals, represent important sources of this contamination [4], such as wastewater with dyes. It is estimated that approximately 700000 tons of wastewater are generated annually worldwide [5], which

*w.silva@ufn.edu.br

Dhttps://orcid.org/0000-0002-7804-9678 have toxic, carcinogenic, and mutagenic characteristics to various organisms [6]. Thus, they present major threats to the environment, especially aquatic biota, including human health $[7,8]$. In parallel, the use of microalgae for wastewater treatment is a good alternative, as some genera are easily found as they proliferate intensely due to the release of nutrient-rich compounds in eutrophic lentic environments such as dams and lakes [9]. In this context, it becomes evident the need to adopt an appropriate treatment for the removal of these contaminants contained in industrial wastewater [10], in order to preserve natural resources, as well as to comply with the norms and legislation on effluent emission standards. Advanced oxidative processes 
(AOPs), technologies with the potential to oxidize/reduce a wide variety of complex organic compounds, have been used as an alternative for wastewater treatment [11] and hydrogen generation [12], highlighting the heterogeneous photocatalysis that through radiation-induced oxi-reduction reactions on the surface of mineral semiconductors (catalysts) promotes the degradation of organic pollutants, being able, in many cases, to correlate the kinetic study with theoretical models [13].

The present study aims to synthesize and characterize activated charcoal from the residual biomass of Chlorella pyrenoidosa microalgae as an evaluation of photocatalytic activity for Rhodamine $\mathrm{B}(\mathrm{RhB})$ dye degradation as a target molecule under UV and visible radiation. In addition, to correlate the photocatalytic activity with the structural and textural properties of synthesized samples. It is noteworthy that this dye was selected, as it is an industrially used dye class. For comparison, $\mathrm{ZnO}$ from Merck was employed, such as a commercial catalyst.

\section{MATERIALS AND METHODS}

Biomass and preparation of activated charcoal: the microalgae used was Chlorella pyrenoidosa powder produced by the company Green Gen. The activated charcoal was prepared based on [14], using the activation/ carbonization process; for chemical activation, the $\mathrm{ZnCl}_{2}$ $(\mathrm{CAQ}, \mathrm{RG})$ was used as activating reagent, in the proportion of $1: 2 \mathrm{w} / \mathrm{w}$, dissolved in $50 \mathrm{~mL}$ of distilled water, followed by magnetic stirring for $30 \mathrm{~min}$. For carbonization, a heating rate of $10{ }^{\circ} \mathrm{C} \cdot \mathrm{min}^{-1}$ up to $600{ }^{\circ} \mathrm{C}$ and holding time for 240 min were used. After cooling to room temperature, the sample was washed with ethanol (Neon, $\mathrm{RG}$ ) to $\mathrm{pH}$ close to 7 (simple filtration) to remove chloride ions and surface ashes. The samples were labeled as microalgae biomass and activated charcoal prepared from microalgae biomass according to Table I. The yield value of activated carbon $\left(\% \mathrm{R}_{\mathrm{AC}-\mathrm{MB}}\right)$ was calculated according to:

$$
\% \mathrm{R}_{\mathrm{AC}-\mathrm{MB}}=\frac{\mathrm{m}_{\mathrm{AC}-\mathrm{MB}}}{\mathrm{m}_{\mathrm{MB}}} \cdot 100
$$

where: $\mathrm{m}_{\mathrm{AC}-\mathrm{MB}}$ : mass of the activated charcoal from microalgae biomass $(\mathrm{g}) ; \mathrm{m}_{\mathrm{MB}}$ : mass of microalgae biomass $(\mathrm{g})$.

Table I - Sample denomination of microalgae biomass and activated charcoal.

[Tabela I - Nomenclatura das amostras de biomassa residual e carvão ativado.]

\begin{tabular}{cc}
\hline Sample & Label \\
\hline Microalgae biomass (Chlorella pyrenoidosa) & MB \\
Activated charcoal from MB & AC-MB \\
\hline
\end{tabular}

Characterization of $M B$ and $A C-M B$ : X-ray diffraction (XRD) was used to determine the crystallinity of the $\mathrm{MB}$ and $\mathrm{AC}-\mathrm{MB}$ in a Bruker D2 Advance diffractometer with a copper tube $(\mathrm{CuK} \alpha=1.5418 \AA)$ in the range of $5^{\circ}$ to $70^{\circ}$
(20), with accelerating voltage and applied current of $30 \mathrm{kV}$ and $30 \mathrm{~mA}$, respectively. A Malvern-Zetasizer nanoZS (ZEN3600) with closed capillary cells (DTS 1060, Malvern) was used to measure the zeta potential values of the samples. $\mathrm{N}_{2}$ porosimetry was used to determine the specific surface area, pore diameter and volume, where the samples (100 to $200 \mathrm{mg}$ ) were degassed at a pressure of $10^{-2}$ mbar at $120{ }^{\circ} \mathrm{C}$ for $12 \mathrm{~h}$ in an equipment Gemini 2375 from Micromeritics. The specific areas $\left(\mathrm{S}_{\mathrm{BET}}\right)$ were determined by the Brunauer-Emmett-Teller (BET) method, in the range of P.P ${ }_{0}^{-1}=0.05$ to 0.35 , while the diameters and volumes of pores by the Barret-Joyner-Halenda (BJH) method. Diffuse reflectance spectroscopy (DRS) was used to determine the band gap energy $\left(\mathrm{E}_{\mathrm{g}}\right)$, using the formula $\mathrm{E}=\mathrm{h} . \mathrm{c} . \lambda^{-1}$, where $\mathrm{h}$ is Plank's constant, $\mathrm{c}$ is the velocity of light, and $\lambda$ is the wavelength. A small amount of sample (about $0.05 \mathrm{~g}$ ) was dispersed over a cell with a quartz window made for analysis of DRS. These samples were analyzed in a UV-vis spectrophotometer (Cary 100 Scan, Varian) with DRA-CA-301 accessory (Labsphere) coupled for diffuse reflectance mode analysis.

Photocatalytic activity: to evaluate the photocatalytic activity, the degradation tests were performed in a jacketed batch reactor with slurry using a solution of $\mathrm{RhB}\left(20 \mathrm{mg} \cdot \mathrm{L}^{-1}\right)$, as the target molecule, and the catalysts. The tests were performed in two stages: a) dark stage (absence of radiation), where adsorption/desorption equilibrium of the target molecule occurred on the surface of the catalyst during 60 $\mathrm{min}$; and b) photocatalytic reaction step (with visible or UV radiation) during $120 \mathrm{~min}$ (sampling at $0,5,15,30,45,60$, 75,90 , and $120 \mathrm{~min}$ ). Then the samples were centrifuged (CT-5000R refrigerated centrifuge, Cientec) for $20 \mathrm{~min}$ with a rotation of $5000 \mathrm{rpm}$ and finally diluted $(0.5 \mathrm{~mL}$ of the sample in $5 \mathrm{~mL}$ of distilled water). The absorbance measurements of the solutions collected during the reaction were carried out in a double-beam spectrophotometer (Cary 100, Varian) with a halogen lamp at the characteristic wavelength of $\operatorname{RhB}(\lambda=553 \mathrm{~nm})$.

Photodegradation kinetics: the kinetic study was conducted as a function of the remaining concentration of $\mathrm{RhB}$ in solution over time. The data were fitted with the kinetic model of Langmuir-Hinshelwood [15, 16], according to:

$$
-r_{i}=-\frac{d C_{i}}{d_{t}}=\frac{\kappa_{s} \cdot K \cdot C_{i}}{1+K \cdot C_{i}}
$$

where: $\kappa_{\mathrm{s}}$ : photodegradation rate of the organic compound; $\mathrm{C}_{\mathrm{i}}$ : concentration of the compound; $\mathrm{t}$ : illumination time; $\mathrm{K}$ : adsorption coefficient of the compound to be degraded. For dilute solutions, the term $1+\mathrm{K} . \mathrm{C}_{\mathrm{i}}$ can be omitted, and the kinetics become pseudo-first-order, according to:

$$
\begin{aligned}
& -r_{i}=-\frac{d C_{i}}{d_{t}}=\kappa_{s} \cdot K \cdot C_{i} \\
& \ln \left(\frac{C_{i 0}}{C_{i}}\right)=\kappa_{s} \cdot K \cdot t=\kappa \cdot t
\end{aligned}
$$


where: $\mathrm{C}_{\mathrm{i} 0}$ : initial concentration of the compound; $\mathrm{C}_{\mathrm{i}}$ : concentration of the compound; $t$ : illumination time. The pseudo-first-order reaction rate constants were determined from the slope of the linear regression of $\ln \left(\mathrm{C}_{0} \cdot \mathrm{C}_{\mathrm{i}}^{-1}\right)$ versus time.

Recycling of the photocatalysts: after the first photodegradation cycle (120 min of irradiation), the treated solution of $\mathrm{RhB}$ was centrifuged (5000 rpm for $20 \mathrm{~min}$ ) to separate the photocatalyst from the solution. Thus, the liquid phase was removed, and the solid phase containing the photocatalyst was carefully separated for reuse. The separated photocatalyst was reintroduced into the reactor for a new identical batch of RhB solution $\left(20 \mathrm{mg} \cdot \mathrm{L}^{-1}\right)$. The entire procedure was repeated 5 times, and the percentage of the photocatalytic reduction (UV and visible radiation) at the end of each cycle was reported.

Statistical analysis: correlation data between photocatalytic activity and characterization results were obtained by Pearson's correlation method using SPSS statistical software (SPSS for Windows, v.19, IBM). All statistical tests were performed at the significance level of $\mathrm{p}<0.05$, where Pearson's correlation coefficient $\left(r_{p}\right)$ was used as a measure of nonparametric statistical dependence between two variables, indicating positive or negative correlations.

\section{RESULTS AND DISCUSSION}

Yield of the chemical activation/carbonization process $(A C-M B)$ : the yield of the synthesis of AC-MB according to the Eq. A was $50.2 \%$, which was in agreement with the literature [17]. It is highlighted that the chemical activation process is relatively effective and can exceed that of the physical activation by up to $30 \%$, besides generating a structure with considerable porosity $[18,19]$.

Characterization of $M B$ and $A C-M B$ : Table II shows the results of $\mathrm{N}_{2}$ porosimetry, DRS, and zeta potential (ZP) characterization. For comparative reasons, the characteristics of a commercial $\mathrm{ZnO}$ catalyst were also determined. According to Table II, MB and AC-MB had a negative surface charge of $-0.5 \pm 4.9$ and $-0.4 \pm 1.2 \mathrm{mV}$, respectively, indicating charge compatibility, favoring attractive forces, since the RhB molecule has cationic characteristics (positive charge) [20]. In addition, samples with ZP in the range of -30 to $+30 \mathrm{mV}$ are characterized by forming more stable

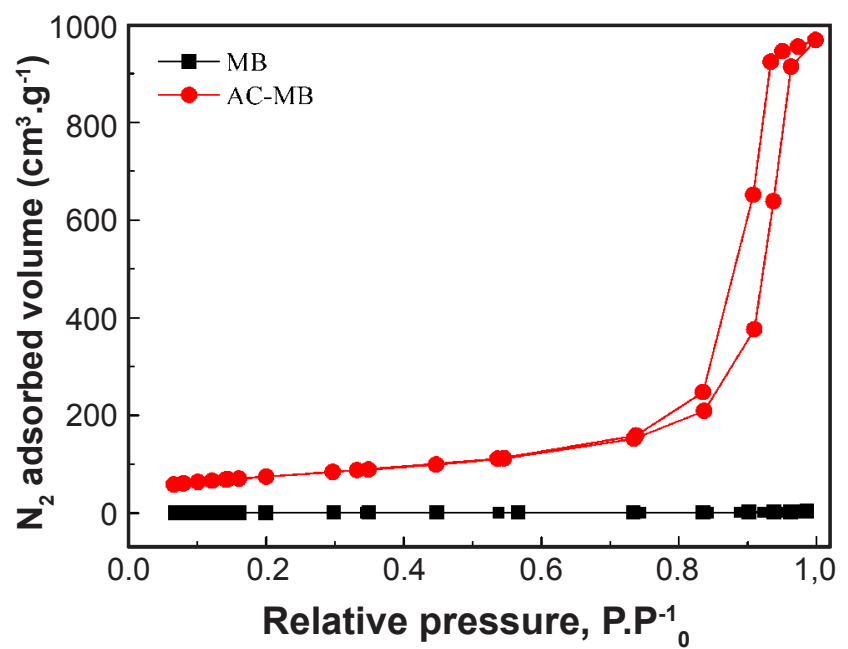

Figure 1: $\mathrm{N}_{2}$ adsorption/desorption isotherms for $\mathrm{MB}$ and $\mathrm{AC}-\mathrm{MB}$. [Figura 1: Isotermas de adsorção/dessorção de $N_{2}$ de $M B$ e AC-MB.]

suspensions, since the surface charge does not allow particle agglomeration to form [21]. Regarding the textural results of $\mathrm{N}_{2}$ porosimetry, the AC-MB sample showed a larger specific area $\left(272 \mathrm{~m}^{2} \cdot \mathrm{g}^{-1}\right)$ as well as a larger pore volume $(1.50$ $\left.\mathrm{cm}^{3} \cdot \mathrm{g}^{-1}\right)$, ideal characteristics for a catalyst, greater number of active sites available, and a higher intra-particle diffusion rate from $\mathrm{RhB}$ to the active site. In addition, according to the International Union of Pure and Applied Chemistry, the samples exhibited characteristics of a mesoporous material, as the pore diameter was between 2 and $50 \mathrm{~nm}$ [22]. Fig. 1 shows MB and AC-MB $\mathrm{N}_{2}$ adsorption/desorption isotherms, indicating type IV isotherms with $\mathrm{H} 3$ hysteresis curves to $\mathrm{AC}-\mathrm{MB}$, according to the Brunauer-Deming-DemingTeller (BDDT) classification. In addition, the hysteresis phenomenon was more pronounced, indicating the presence of mesoporous.

X-ray diffraction was used to identify the composition and crystalline phases present in the samples. The diffractograms of MB and AC-MB samples are shown in Fig. 2a. It was possible to verify that the MB sample had an amorphous structure with a wide amorphous peak at approximately $2 \theta=20^{\circ}$, mainly due to the in natura microalgae composition (predominant of proteins and carbohydrates) [23]. The ACMB showed the $\mathrm{ZnO}$ crystalline phase in the hexagonal form with wurtzite structure, lattice parameters $\mathrm{a}=0.3242 \mathrm{~nm}$ and $\mathrm{c}=0.5188 \mathrm{~nm}$ and space group $\mathrm{P} 63 \mathrm{mc}$, with characteristic

Table II - Surface area $\left(\mathrm{S}_{\mathrm{BET}}\right)$, pore diameter $\left(\mathrm{D}_{\mathrm{p}}\right)$, pore volume $\left(\mathrm{V}_{\mathrm{p}}\right)$, band gap energy $\left(\mathrm{E}_{\mathrm{g}}\right)$, and zeta potential $(\mathrm{ZP})$ of the $\mathrm{MB}$, $\mathrm{AC}-\mathrm{MB}$, and commercial $\mathrm{ZnO}$.

[Tabela II - Área superficial $\left(S_{B E T}\right)$, diâmetro de poros $\left(D_{p}\right)$, volume de poros $\left(V_{p}\right)$, energia de band gap $\left(E_{g}\right)$ e potencial zeta (ZP) de $M B, A C-M B$ e ZnO comercial.]

\begin{tabular}{cccccc}
\hline Sample & $\mathrm{S}_{\mathrm{BET}}\left(\mathrm{m}^{2} \cdot \mathrm{g}^{-1}\right)$ & $\mathrm{D}_{\mathrm{p}}(\mathrm{nm})$ & $\mathrm{V}_{\mathrm{p}}\left(\mathrm{cm}^{3} \cdot \mathrm{g}^{-1}\right)$ & $\mathrm{E}_{\mathrm{g}}(\mathrm{eV})$ & $\mathrm{ZP}(\mathrm{mV})$ \\
\hline $\mathrm{MB}$ & $2.8 \pm 0.5$ & $14.3 \pm 0.5$ & $0.005 \pm 0.001$ & $5.6 \pm 0.2$ & $-0.5 \pm 4.9$ \\
$\mathrm{AC}-\mathrm{MB}$ & $272.0 \pm 0.5$ & $20.1 \pm 0.5$ & $1.50 \pm 0.02$ & $2.6 \pm 0.2$ & $-0.4 \pm 1.2$ \\
Commercial ZnO & $27.0 \pm 0.5$ & $33.0 \pm 0.5$ & $0.029 \pm 0.002$ & $3.3 \pm 0.2$ & $-25.0 \pm 0.5$ \\
\hline
\end{tabular}



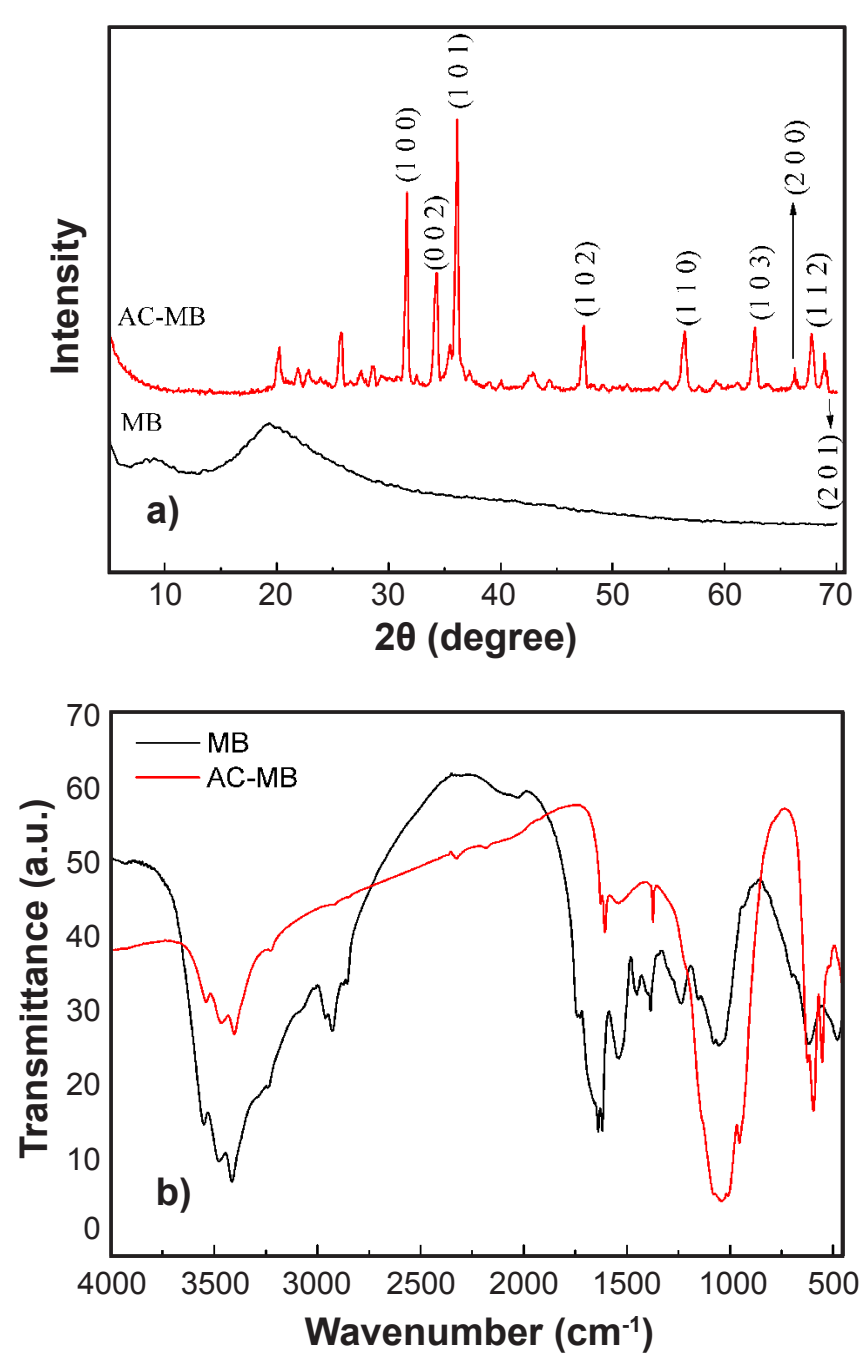

Figure 2: XRD patterns (a) and FTIR spectra (b) for MB and AC-MB. [Figura 2: Difratogramas de raios $X(a)$ e espectros de FTIR (b) de $M B$ e $A C-M B$.]

peaks and planes at $31.5^{\circ}(100), 34.2^{\circ}(002), 36.1^{\circ}(101)$, $47.3^{\circ}(102), 56.3^{\circ}(110), 62.7^{\circ}(103), 66.2^{\circ}(200), 67.7^{\circ}(112)$, and $68.8^{\circ}$ (201) [24], according to the Joint Committee on Powder Diffraction Standard (JCPDS - $\mathrm{n}^{\circ}$ 01-075-0576), coming from the precursor of chemical activation $\left(\mathrm{ZnCl}_{2}\right)$. FTIR analysis was used as a qualitative technique to identify functional groups present in synthesized materials. Spectra obtained for MB and AC-MB samples are shown in Fig. $2 \mathrm{~b}$. It was possible to identify some characteristic peaks in common, such as [25]: 1) broad, strong peak at 3200-3500 $\mathrm{cm}^{-1}$ was attributed to the absorption of $\mathrm{O}-\mathrm{H}$ group consisting of the free $\mathrm{O}-\mathrm{H}$ stretch together with hydrogen-bonded $\mathrm{O}-\mathrm{H}$ in $\mathrm{MB}$ and $\mathrm{AC}-\mathrm{MB}$; 2) bands at 1400 to $1650 \mathrm{~cm}^{-1}$ range suggested the presence of some acetate moieties on the surface; 3) bands at 1100 to $1250 \mathrm{~cm}^{-1}$ region were attributed to $\mathrm{C}-\mathrm{O}$ stretch coupled with $\mathrm{C}-\mathrm{C}$ stretching vibration; and 4) peak at $535 \mathrm{~cm}^{-1}$ showed the metal oxide ( $\left.\mathrm{Zn}-\mathrm{O}\right)$.

Photocatalytic activity: of $\mathrm{MB}$ and $\mathrm{AC}-\mathrm{MB}$, as well as for the commercial $\mathrm{ZnO}$, was carried out by the photodegradation of $\mathrm{RhB}$, under UV and visible radiation, according to predetermined methodology [26]. According to
Fig. 3, after $120 \mathrm{~min}$ of UV radiation, $8.4 \%(\mathrm{k}=0.0007$ $\left.\mathrm{min}^{-1}\right), 75.5 \%\left(\mathrm{k}=0.0112 \mathrm{~min}^{-1}\right)$, and $92.5 \%\left(\mathrm{k}=0.0158 \mathrm{~min}^{-1}\right)$ of $\mathrm{RhB}$ were degraded using $\mathrm{MB}, \mathrm{AC}-\mathrm{MB}$, and commercial $\mathrm{ZnO}$, respectively, while $5.9 \%\left(\mathrm{k}=0.0005 \mathrm{~min}^{-1}\right), 66.5 \%$ $\left(\mathrm{k}=0.0091 \mathrm{~min}^{-1}\right)$, and $16.6 \%\left(\mathrm{k}=0.0032 \mathrm{~min}^{-1}\right)$ of $\mathrm{RhB}$ under visible radiation were degraded using $\mathrm{MB}$, AC$\mathrm{MB}$, and commercial $\mathrm{ZnO}$, respectively. Moreover, the significant increase of the surface area (27 to $272 \mathrm{~m}^{2} \cdot \mathrm{g}^{-1}$ ) and the reduction in the band gap energy (3.3 to $2.6 \mathrm{eV}$ ) provided an increase on the photocatalytic activity of the AC-MB, mainly under visible radiation, since it enhanced the electron transfer properties of the photocatalyst, as well as the number of active sites available for RhB dye degradation and lower energy required for photoactivation of the catalyst. The activation/carbonization processes of $\mathrm{MB}$ promoted an increase in the photocatalytic activity on the $\mathrm{RhB}$ degradation under UV radiation (about 8 times
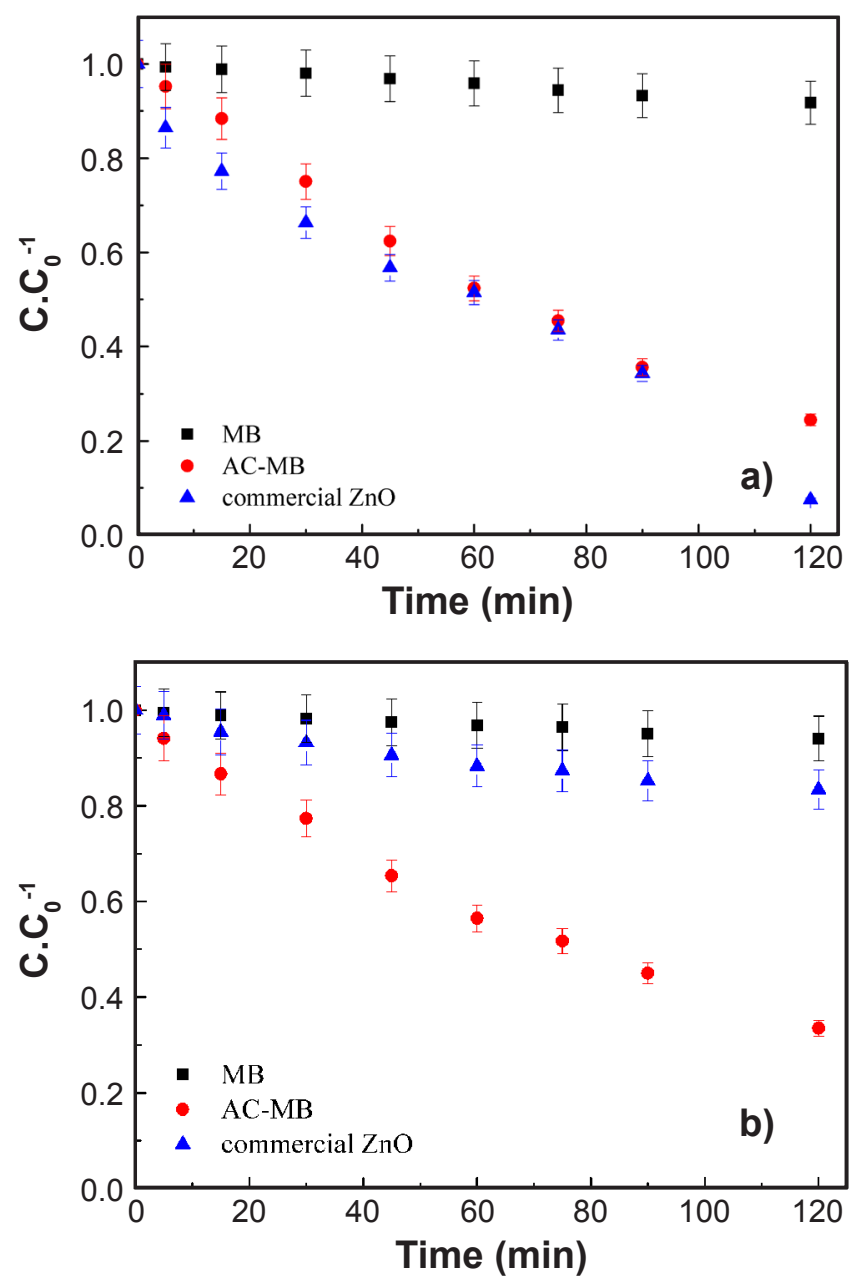

Figure 3: Photocatalytic activity of MB, AC-MB, and commercial $\mathrm{ZnO}$ on $\mathrm{RhB}$ degradation under UV (a) and visible (b) radiation after 120 $\min \left([\right.$ catalyst $]=0.7 \mathrm{~g} . \mathrm{L}^{-1},[\mathrm{RhB}]=20 \mathrm{mg} . \mathrm{L}^{-1}, \mathrm{~T}=30^{\circ} \mathrm{C}, \mathrm{pH}=4.43, \mathrm{UV}$ radiation of $61.8 \mathrm{~W} \cdot \mathrm{m}^{-2}$, visible radiation of $202 \mathrm{~W} \cdot \mathrm{m}^{-2}$, and error $5 \%$ ).

[Figura 3: Atividade fotocatalítica de $\mathrm{MB}, \mathrm{AC}-\mathrm{MB}$ e ZnO comercial na degradação da $R h B$ sob radiação $U V($ a) e visível (b) após $120 \mathrm{~min}$ ([catalisador] $=0,7 \mathrm{~g} \cdot \mathrm{L}^{-1},[\mathrm{RhB}]=20 \mathrm{mg} \cdot \mathrm{L}^{-1}$, $T=30^{\circ} \mathrm{C}, \mathrm{pH}=4,43$, radiação $U V$ de $61,8 \mathrm{~W} . \mathrm{m}^{-2}$, radiação visível de 202 W.m m $^{-2}$ e erro de 5\%).] 

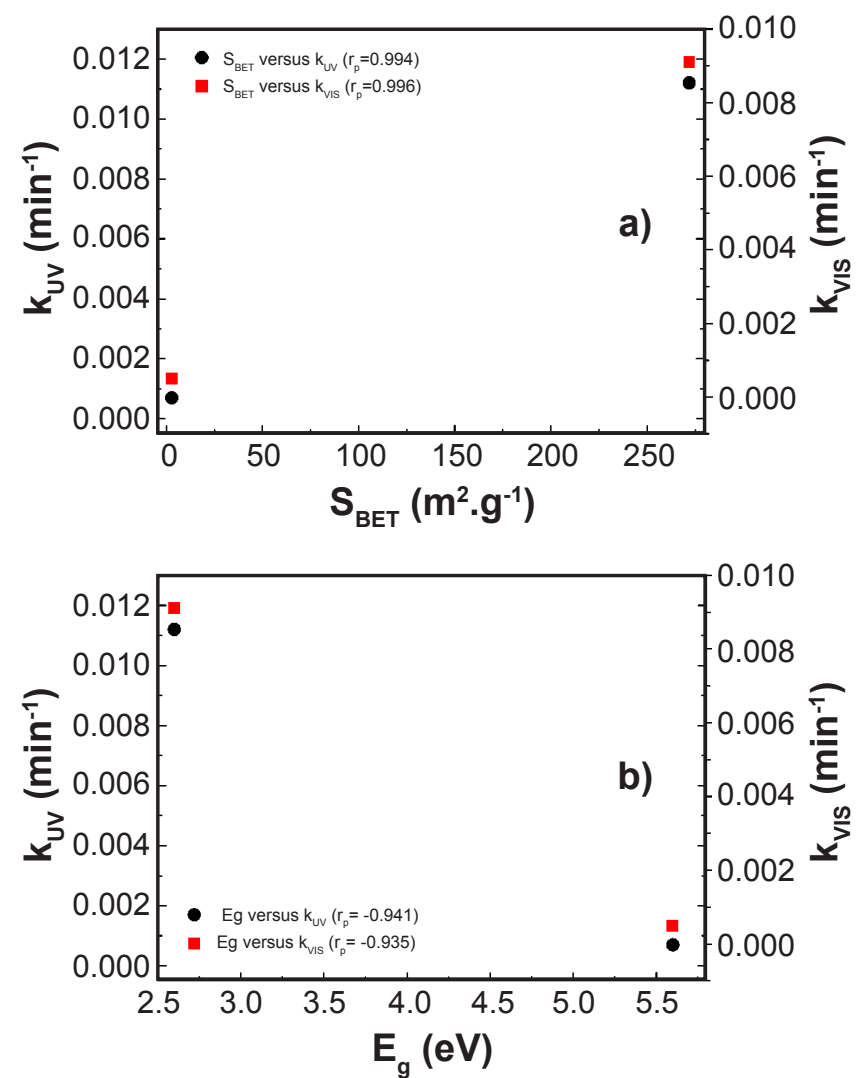

Figure 4: Correlations between specific reaction velocity $(k)$ of RhB degradation under UV and visible radiation with (a) surface area $\left(\mathrm{S}_{\mathrm{BET}}\right)$ and (b) band gap energy $\left(\mathrm{E}_{\mathrm{g}}\right)$.

[Figura 4: Correlações entre a velocidade específica de reação $(k)$ de degradação da $R h B$ sob radiação $U V$ e visível com (a) área superficial $\left(S_{B E T}\right)$ e a energia de band gap $\left.\left(E_{g}\right).\right]$

under UV radiation and 11 times under visible radiation). This can be explained due to the significant increase in specific surface area, as well as pore volume, and decrease of band gap energy. Thus, there is an increase in the number of active sites available, as well as an increase in the internal diffusion of RhB molecules, promoting a higher generation of hydroxyl radicals [27]. Moreover, the decrease of band gap energy promoted enhance of the photoexcited electron to the conduction band and simultaneously increasing the electron transfer to the adsorbed $\mathrm{O}_{2}$, reducing possible combinations of electron-hole pairs, increasing photocatalytic activity [28].

Some of Pearson's main correlations were observed, using the SPSS statistical software, according to Fig. 4. Fig. 4a shows a direct correlation between surface area $\left(\mathrm{S}_{\mathrm{BET}}\right)$ and respective specific reaction velocity $(\mathrm{k})$ under $\mathrm{UV}\left(\mathrm{r}_{\mathrm{p}}=0.994\right)$ and visible $\left(r_{p}=0.996\right)$ radiation, indicating that for a larger specific surface area, higher the specific reaction velocity, since more active sites are available, thus greater the RhB adsorption and higher the generation of hydroxyl radicals. Moreover, Fig. 4b showed an indirect correlation of band gap energy, $\mathrm{E}_{\mathrm{g}}\left(\mathrm{r}_{\mathrm{p}}=-0.941\right.$ and -0.935 under UV and visible radiation, respectively), indicating that for lower $\mathrm{E}_{\mathrm{g}}$ values, higher the specific reaction velocity, as photocatalysts are more easily activated, facilitating oxi-reduction reactions for degradation of organic pollutants providing greater photocatalytic activity in target molecule degradation under $\mathrm{UV}$ and visible radiation.

On the mechanism of heterogeneous photocatalysis, AC-MB photooxidation instigated the photocatalysis of $\mathrm{RhB}$ in solution, leaving the catalyst surface with a strong oxidative potential of an electron-hole pair $\left(\mathrm{e}_{\mathrm{CB}}^{-}+\mathrm{h}^{+}{ }_{\mathrm{VB}}, \mathrm{Eq}\right.$. $\mathrm{E})$, when photocatalyst was irradiated with higher energy than that of band gap energy $\left(E_{g}\right)$, which allowed the oxidation of the $\mathrm{RhB}$ molecule in a direct manner to the reactive intermediates (Eq. F). The hydroxyl radical $\left(\mathrm{OH}^{\circ}\right)$, the exceptionally strong and a non-selective oxidant, which is formed either by decomposition of water (Eq. G) or by the reaction of the hole along with hydroxyl ion, $\mathrm{OH}^{-}(\mathrm{Eq} . \mathrm{H})$, is also responsible for the degradation of phenol molecule, leading to incomplete or complete mineralization of many organic molecules (Eq. I) [28].

$$
\begin{aligned}
& \mathrm{AC}-\mathrm{MB}+\mathrm{h} . v \rightarrow \mathrm{AC}-\mathrm{MB}\left(\mathrm{e}_{\mathrm{CB}}^{-}+\mathrm{h}^{+}{ }_{\mathrm{VB}}\right) \\
& \left(\mathrm{h}^{+}{ }_{\mathrm{VB}}\right)+\mathrm{RhB} \rightarrow \mathrm{RhB}^{\cdot+} \rightarrow \text { oxidation of } \mathrm{RhB} \text { molecule } \\
& \left(\mathrm{h}^{+}{ }_{\mathrm{VB}}\right)+\mathrm{H}_{2} \mathrm{O} \rightarrow \mathrm{H}^{+}+\mathrm{HO}^{\cdot} \\
& \left(\mathrm{h}^{+}{ }_{\mathrm{VB}}\right)+\mathrm{HO}^{-} \rightarrow \mathrm{HO}^{\cdot} \\
& \mathrm{HO}^{-}+\mathrm{RhB} \rightarrow \text { degradation of } \mathrm{RhB} \text { molecule }
\end{aligned}
$$

Effect of $A C-M B$ recycling: the effect of reuse of the AC$\mathrm{MB}$ catalyst under UV and visible radiation was evaluated 5 times. According to Table III, the AC-MB catalyst showed a photostability after 5 recycling processes, with a small decrease (about 10\%) in the photocatalytic activity $(75.5 \%$ to $68.0 \%$ under UV radiation and $66.5 \%$ to $59.8 \%$ under visible radiation).

Table III - Effect of AC-MB catalyst reuse on the degradation of the RhB.

[Tabela III - Efeito da reutilização do catalisador AC-MB na degradação do $R h B$.]

\begin{tabular}{ccc}
\hline Cycle number & $\begin{array}{c}\text { UV degradation } \\
(\%)\end{array}$ & $\begin{array}{c}\text { Visible } \\
\text { degradation }(\%)\end{array}$ \\
\hline I (fresh catalyst) & 75.5 & 66.5 \\
II & 73.2 & 64.5 \\
III & 72.7 & 63.2 \\
IV & 71.2 & 62.2 \\
V & 69.4 & 61.4 \\
VI & 68.0 & 59.8 \\
\hline
\end{tabular}

\section{CONCLUSIONS}

According to the characterization and photocatalytic activity results, the activation/carbonization processes with $\mathrm{ZnCl}_{2}$ caused positive changes in the properties 
of the microalgae biomass Chlorella pyrenoidosa for heterogeneous photocatalysis, such as reduction of band gap energy (5.6 to $2.6 \mathrm{eV}$ ), the increase of surface area (2.8 to $\left.272 \mathrm{~m}^{2} \cdot \mathrm{g}^{-1}\right)$, and the increase in photocatalytic activity under UV and visible radiation. Therefore, activated charcoal from microalgae biomass is a great option to improve the photocatalytic performance for the degradation of organic pollutants (such as dyes) by heterogeneous photocatalysis.

\section{ACKNOWLEDGMENTS}

We thank the Laboratory of Catalysis and Polymers (K106) of the Federal University of Rio Grande do Sul (UFRGS) and Nanotechnology Laboratory (S013) of the Franciscan University for the support and assistance to carry out the present work. Moreover, this work received financial support from the Foundation for Research of the State of Rio Grande do Sul (FAPERGS - Project 19/2551-0001362-0), so all thanks.

\section{REFERENCES}

[1] O. Kiguchi, G. Sato, T. Kobayashi, Environ. Sci. Pollut. R. 23, 22 (2006) 22513.

[2] L. Mandaric, E. Diamantini, E. Stella, K. Cano-Paoli, J. Valle-Sistac, D. Molins-Delgado, A. Bellin, G. Chiogna, B. Majone, M.S. Diaz-Cruz, S. Sabater, D. Barcelo, M. Petrovic, Sci. Total Environ. 590-591, 1 (2017) 484.

[3] S.A. Noorhosseini, M.S. llahyari, C.A. Damalas, S.S. Moghaddam, Sci. Total Environ. 599-600, 1 (2017) 2019.

[4] M.A. Salem, A.F. Al-Ghonemiy, A.B. Zaki, Appl. Catal. B Environ. 91, 1-2 (2009) 59.

[5] D. Bhatia, N.R. Sharma, J. Singh, R.S. Kanwar, Crit. Rev. Env. Sci. Tec. 47, 19 (2017) 1836.

[6] K. Piaskow, R. Świderska-Dabrowska, P.K. Zarzycki, J. AOAC Int. 101, 5 (2018) 1371.

[7] D.E. Alipanahpour, M. Ghaedi, A. Asfaram, F. Mehrabi, A.A. Bazrafshan, Ultrason. Sonochem. 40, A (2018) 238.

[8] P.S. Thue, A.C. Sophia, E.C. Lima, A.G.N. Wamba, W.S. De Alencar, G.S. Dos Reis, F.S. Rodembusch, S.L.P. Dias, J. Clean. Prod. 171, 1 (2018) 30.
[9] E. Kwietniewska, J. Tys, Renew. Sust. Energ. Rev. 34, 1 (2014) 491.

[10] A. Bhatnagar, M. Sillanpää, Chem. Eng. J. 157, 2-3 (2010) 277.

[11] K.S. Araújo, R. Antonelli, B. Gaydeczka, A.C. Granato, G.R.P. Malpass, Rev. Amb. Água 11, 2 (2016) 387.

[12] C. Nguyen, N.Vu, S. Chabot, S. Kaliaguine, T. Do, Solar RRL 1, 5 (2017) 1700012.

[13] A.E. Kasmi, G. Pan, L. Wu, Z. Tian, Sci. Bull. 64, 9 (2019) 625.

[14] M.A. Schettino Jr., J.C.C. Freitas, A.G. Cunha, F.G. Emmerich, Quim. Nova 30, 7 (2007)1663.

[15] P.R. Gogate, A.B. Pandit, Adv. Environ. Res. 8, 3-4 (2004) 501.

[16] U.I. Gaya, A.H. Abdullah, J. Photochem. Photobio. C 9, 1 (2018) 1 .

[17] W. Kwapinski, C.M.P. Byrne, E. Kryachko, P. Wolfram, C. Adley, J.J. Leahy, E.H. Novotny, M.H.B. Hayes, Waste Biomass Valori. 1, 2 (2010) 177.

[18] M.A.M. Salleh, D.K. Mahmoud, W.A.W.A. Karim, A. Idris, Desalination 280, 1-3 (2011) 1.

[19] E.C. Peres, J. Environ. Chem. Eng. 6, 1 (2108) 677.

[20] A. Debrassi, A.F. Corrêa, T. Baccarin, N. Nedelko, A. Ślawska-Waniewska, K. Sobczak, P. Dłużewski, J. Greneche, C.A. Rodrigues, Chem. Eng. J. 183, 1 (2011) 284.

[21] J.V. Mohanraj, Y. Chen, Trop. J. Pharm. Res. 5, 1 (2006) 561.

[22] IUPAC, Pure Appl. Chem. 31, 4 (1972) 578.

[23] A.L.D. Da Rosa, E. Carissimi, G.L. Dotto, H. Sander, L.A. Ferris, J. Clean. Prod. 198, 1 (2018) 1302.

[24] T.M. Sabine, S. Hogg, Acta Cryst. 25, 1 (1969) 2254.

[25] E.V. Benvenutti, C.C. Moro, T.H. Costa, M.R. Gallas, Quim. Nova 32, 7 (2009) 1926.

[26] W.L. Da Silva, M.A. Lansarin, J.H.Z. Dos Santos, Water Sci. Technol. 73, 1 (2016) 28.

[27] A. Gnanaprakasam, V.M. Sivakumar, M. Thirumarimurugan, Indian J. Mater. Sci. 1, (2015) 601827. [28] S.K. Kansal, M. Singh, D. Sud, J. Hazard. Mater. 141, 3 (2007) 581 .

(Rec.11/02/2020, Rev.30/03/2020, 12/04/2020, 08/05/2020, Ac. 11/05/2020) 